\title{
A FUNÇÃO DO MITO NOS DIREITOS HUMANOS: UM PROGRAMA DE ESTUDOS SOBRE PERFORMATIVIDADE DO DISCURSO JURÍDICO
}

\section{(THE ROLE OF THE MYTH IN HUMAN RIGHTS: A STUDY PROGRAM ON PERFORMATIVITY OF LEGAL DISCOURSE)}

\author{
Manoel Uchôa ${ }^{1}$ \\ Stefano Toscano ${ }^{2}$
}

DOI: $\quad 10.20399 / \mathrm{P} 1982-999 X .2015 v 1 n 2 p p 89-111$

\begin{abstract}
Resumo: O mito é uma fala. Segundo Roland Barthes, há uma forma de significação que constitui o cotidiano das relações sociais na medida em que seu significado é esvaziado em prol da repetição de seu significante. Nessa repetição, a teoria dos atos de fala tratadas por Jacques Derrida expõem a possibilidade de criticar o processo de violência mítica que institui o direito e suas formas de enunciação. Pretende-se analisar de que forma é possível identificar uma injunção entre Direito, mito e violência na constituição dos Direitos Humanos na modernidade.
\end{abstract}

Palavras-chave: Mito; Performatividade; Direitos Humanos;

\begin{abstract}
The myth is a speech. According to Roland Barthes, there is a form of meaning that constitutes the everyday social relations in that its meaning is emptied for the sake of repetition of his significant. In this repetition, the theory of speech acts treated by Jacques Derrida expose the possibility of criticizing the process of mythic violence imposing the duty and its forms of enunciation. It intends to analyze how it is possible to identify an order of law, myth and violence in the constitution of Human Rights in modernity.
\end{abstract}

Key-words: Myth; Performativity; Human Rights;

Introdução.

A constituição de um discurso encontra seu espaço e entre os choques de outros discursos que operam em sua justaposição. Falas, declarações, segredos formam uma materialidade textual de pretensões totalizantes. Não à toa, a noção de jogo passou a oferecer uma orientação sobre o uso dos discursos. Ora os textos parecem mais adensados ora menos; o que leva ao questionamento da consistência dos argumentos. Nesse sentido, os direitos humanos são um discurso que acumulou densidade na sociedade contemporânea.

É sensível a diversas demandas sociais recair no tratamento dos direitos humanos. Seja uma ação violenta perpetrada por agentes estatais seja a proibição de permanência de uma criança na escola por um certo tipo de corte de cabelo, as demandas expõem a reiteração dum "direito humano a". Na lição de Bobbio, a era dos direitos é a expansão e sedimentação de que os processos sociais são perpassados pelo

1Manoel Carlos Uchôa de Oliveira. Doutorando no PPGCJ/UFPB. Professor Assistente I na Unicap. E-mail: manoel.cuo@gmail.com

2 Stefano Gonçalves Regis Toscano. Doutor pelo PPGD/UFPE. Professor Adjunto I da Unicap. E-mail: stefanotoscano@hotmail.com 
reconhecimento de uma cultura de direitos subjetivos inscritas nas declarações nos planos nacionais e internacionais (1992). Cada nação inserida no rol dos signatários parece endossar e adensar o jogo deste discurso. Seria possível, então, na repetição de seus enunciados tornar sua demanda universal para todo o mundo civilizado.

Uma condição crucial para um discurso expandir e acumular valor será necessariamente sua repetição (DERRIDA, 1984). Para tanto, é necessário compreender o processo de circulação da economia discursiva. É preciso compreender que a produção de um discurso depende de uma economia própria e está relacionada à sua circulação. Isto é, quanto mais um discurso se apresenta nas interações sociais mais produtivo ele se faz. Não seria seu valor de uso que o define, mas o valor de troca. A filosofia e teoria do Direito produzem, assim, uma usura para suas categorias. Logo, os Direitos Humanos também encontram seu valor neste processo. Sua força depende da usura.

Há uma forma de discurso que interage e transpassa as relações sociais com mais eficiência: é o caso do mito. A fala mitificada consegue articular tanto o espaço cognitivo quanto o espaço normativo de uma sociedade. É um fenômeno duplo: "É o que se passa com a mitologia: faz parte simultaneamente da semiologia, como ciência formal, e da ideologia, como ciência histórica: ela estuda idéias-em-forma" (BARTHES, 2010, p. 203). Então, é preciso analisar o mito do ponto de vista estrutural e histórico. De acordo com os fins deste trabalho, dar-se-á ênfase a perspectiva estrutural, sem dispensar de todo o caráter histórico do estudo.

Antes de ser um mero instrumento, o mito é o próprio lastro do saber e do poder na medida em que organiza a práxis, por conseguinte, deve-se reconhecer e analisar os direitos humanos enquanto um mito na sociedade moderna. A pretensão deste trabalho é explicar os direitos humanos enquanto discurso mitificado. As condições para esta adjetivação recaem menos em tratar o mito dos direitos humanos por um critério de falsidade ou verdade. Trata-se, antes de tudo, de procurar entender que força é investida em sua circulação.

A teoria dos Direitos Humanos reitera um padrão de problemas a cada obra ou debate realizados. Qual o fundamento dos Direitos Humanos? De que ordem natural ou positiva eles emergem? São esses direitos universais ou contingentes? Como concretizar as suas prescrições em relação às demandas reais? O que se propõe para oferecer uma resposta a essas perguntas, ainda que não seja possível respondê-las completamente, 
considerando os limites deste trabalho, é analisar o caráter semiológico dos Direitos Humanos através do conceito de mito.

O mito é a forma através da qual é possível afirmar a necessidade dos Direitos ainda que em uma ordem convencional. Sua universalidade, mesmo em meio a mudança histórica, é fruto da mitologia que opera discursivamente. Sua concretização se dá na capacidade do mito de interferir na ação individual e coletiva. Nesse sentido, é importante interpretar o mito para além do bem e do mal. Contudo, é preciso esclarecer que na instituição dos Direitos há um papel violento permeando na forma do mito. Se, por um lado, há um vazio de significado, por outro, sua forma revela uma interdependência com a força que se exerce por e para ele.

Os Direitos Humanos permanecem no limiar entre a política e o direito. Sua pretensão é de fundamentação da sociedade contemporânea. Seu uso é da ordem da autoridade da emancipação humana e da legitimidade de suas instituições políticojurídicas. Expressa-se frequentemente como uma ode à civilização contrária à barbárie e à violência. Entretanto, é possível entrever que processo violento é ocultado na emergência e na afirmação dos Direitos Humanos? No esteio do trabalho de Costas Douzinas (2000), por exemplo, o paradoxo deste discurso não operaria justamente no ponto em que a liberação dos povos conjuga-se com a possibilidade de seu massacre? Nesse ponto, o triunfo seria duplo: constituir um fundamento à civilidade e um esquecimento da violência que a criou. O triunfo é a própria finalidade do mito.

A proposta deste trabalho se divide em dois pontos principais. Primeiro, é preciso esclarecer o conceito de mito na modernidade. Sob uma dupla perspectiva, o mito é um fenômeno semiológico e político. Por um lado, é uma forma de falar e estabelecer uma comunicação; por outro, possui um caráter normativo que impele a atividade. Segundo, é preciso analisar que quais forças operam através do mito. Sua violência tem raízes simbólicas e históricas. Por isso, pretende-se explicitar a função mítica dos Direitos Humanos. Nesse ponto, esse discurso precisa ser lido como um mito de segunda ordem. Por sua repetição, a mitificação precisa mudar para preservar a si mesma.

10 que se entende por mito? O mito como forma iterável de comunicação - um ato performativo: Barthes com Derrida. 
O mito é uma fala. Segundo Roland Barthes, "ele é um modo de significação, uma forma" (BARTHES, 2010, p. 199). Há uma forma de significação que constitui o cotidiano das relações sociais na medida em que seu significado é esvaziado em prol da repetição de seu significante. Tal experiência leva ao reconhecimento de um mito na medida em que as pessoas se vinculam a uma determinada expressão atribuindo uma ordem de significação secundária, não referida de imediato na mensagem:

\begin{abstract}
Seria, portanto, totalmente ilusório pretender fazer uma discriminação substancial entre os objetos míticos: já que o mito é uma fala, tudo pode constituir mito, desde que seja suscetível de ser julgado por um discurso. $\mathrm{O}$ mito não se define pelo objeto da mensagem, mas pela maneira como a profere: o mito tem limites formais, contudo não substanciais. (BARTHES, 2010, p. 199)
\end{abstract}

A significação depende de uma sincronia entre o significante e o significado. Isto é, há um vínculo imediato e instantâneo entre o registro indicativo e a imagem mental de um signo. Entretanto, duas características do signo abalam essa relação. O signo é arbitrário e imotivado. De uma vez, não há razão que fundamente os processos de significação. A estrutura do sentido é a trindade entre signo, significante e significado. Contudo, o que permite uma certeza ao sentido é a estabilização histórica de seu uso, em outras palavras, seu contexto:

Naturalmente, este esquema tridimensional, por mais constante que seja em sua forma, não se efetua sempre da mesma maneira: logo, nunca será demasiado repetir que a semiologia só pode comportar uma unidade no nível das formas, e não dos conteúdos; o seu campo é limitado, tem por objeto apenas uma linguagem e só conhece uma operação: a leitura ou o deciframento. (BARTHES, 2010, p. 204)

O mito torna-se uma codificação sobre a codificação. Nesse ponto, burla-se tanto a sincronia quanto o contexto. A tridimensionalidade é replicada aproveitando-se do "sem fundo" do signo para promover o deslocamento e o aprisionamento do sentido nas relações sociais:

\footnotetext{
O mito entendido como um discurso de crenças e valores que correspondem à memória coletiva de uma sociedade, é utilizado com frequência como elemento da retórica discursiva do governante, com a intenção de motivar e persuadir, embora pouco se tenha explorado a capacidade de sua aplicação como elemento estratégico de comunicação. (NIETO, 2012, p. 140)
}

Como se trata de um sistema de comunicação, um processo estritamente formal: "visto que ele se constrói a partir de uma cadeia semiológica que já existe antes dele: é um sistema semiológico segundo" (BARTHES, 2010, p. 205). Na medida em que um determinado signo carrega um sentido, o mito é uma significação de segunda ordem. Isto é, Na estrutura da mensagem, ele se aloja como um sentido acessório e suplementar, 
pois toma o lugar da mensagem principal: "O significante do mito se apresenta de uma maneira ambígua: é simultaneamente sentido e forma, pleno de um lado, vazio do outro lado" (2010, p. 208). O que há de curioso é que o mito não se esconde do processo:

Pode-se constatar, assim, que no mito existem dois sistemas semiológicos, um deles descolado em relação ao outro: um sistema linguístico, a língua (ou os modos de representação que lhe são comparados), que chamarei de linguagem-objeto, porque é a linguagem de que o mito se serve para construir o seu próprio sistema: e o próprio mito, que chamarei de metalinguagem, porque é uma segunda língua, na qual se fala da primeira. (BARTHES, 2010, p. 206)

Há, na verdade, um suplemento que não elimina a mensagem principal, mas nos impossibilita de lidar com as possibilidades interpretativas dessa mensagem. O mito é parasitário. Logo, a mensagem perde seu contexto artificial para ser naturalizada: "A elaboração de um segundo sistema semiológico vai permitir que o mito escape ao dilema: obrigado a revelar ou liquidar o conceito, naturaliza-o. (...) Atingimos assim o próprio princípio do mito: transforma a história em natureza" (BARTHES, 2010, p. 221).

A ordem natural da significação do mito impõe uma disposição necessária entre a mensagem imediata e a mediação do mito. Assim, a principal consequência do mito é naturalizar as relações sociais, isto é, artificiais. Como é um processo formal, podemos analisá-lo em sua estrutura. Contudo, o mito substancialmente não tem limites. Qualquer informação pode ser mitificada. Este é seu perigo: cria uma cadeia de equivalência onde não há, mas faz ver, ouvir e seguir uma imperatividade que lhe é própria.

O mito é uma fala roubada. Sua forma consiste em roubar (não há roubo sem imperatividade) a mensagem primária convertendo em uma fala natural e pretensamente despolitizada. Opera-se na imperatividade mítica um conformismo e um empobrecimento da vida. Diante de todas as possibilidades de sentido e ação, o mito registra uma restrição na própria apreensão do mundo social. É a perda da discursividade e pluralidade premente à vida política.

Não é à toa que por essa ambiguidade entre o sentido da mensagem primária e o sentido roubado e cristalizado do mito é preciso dividir seu estudo entre a semiologia e a ideologia. Por um lado, o mito refere-se a um processo formal num discurso que se vê expropriado de seu sentido. Por outro, o mito tem uma história que não quer revelar para manter sua mensagem como natural. 
Não é preciso ter lido Barthes para observar a dupla mensagem carregada pelos referentes. O mito não elimina a presença da mensagem primária, porém não permite que ela seja contemplada de outro modo. É por isso que o trabalho do mitólogo não é nunca pleno, pois expor o mito é bater numa porta aberta. É preciso reiterar o mito com pretensões a banalizar seu processo:

\begin{abstract}
O mito possui um caráter imperativo, interpelador: tendo surgido de um conceito histórico, vindo diretamente da contingência (uma aula de latim, $\mathrm{O}$ Império ameaçado), é a mim que ele se dirige. Está voltado para mim, impõeme a sua força intencional; obriga-me a acolher a sua ambiguidade expansiva. (BARTHES, 2010, p. 216)
\end{abstract}

A imperatividade consiste na qualidade primordial do mito na medida em que pode ser dimensionado na positividade do Direito. O saber jurídico não é outra coisa senão esse deslocamento do signo formando um sistema semiológico secundário para o exercício do poder. Há uma relação interna entra a violência e a linguagem no interior do campo jurídico que encontra no mito sua expressão mais sofisticada. Confere-se, então, uma função prescritiva à organização social da autoridade do Direito. O mito é o reforço imprescindível:

fortalecer e elevar a tradição ao registrar maior valor, nível e uma realidade supernatural dos eventos considerados primitivos. $\mathrm{O}$ mito ressalta, expressa e codifica crenças, reforçar a moral e contem regras práticas como guia para $\mathrm{o}$ homem. (NIETO, 2012, p. 142)

Sob pontos estratégicos, o Direito agencia o mito para controlar a circulação dos discursos sociais. Traduzir as demandas sociais, os conflitos políticos em linguagem jurídica é o primeiro passo para controlar seus termos em vista de uma anulação de sua potência. Ainda que, num sentido contrário, George Sorel, ao investigar o mito, indica que ele impulsiona a ação, logo, possui um caráter político. Isso será aprofundado no ponto seguinte, mas é possível compreender que o caráter político do mito é a despolitização.

Ora, as declarações de Direitos (humanos) têm em vista converter o problema de uma demanda política pela condição humana em preceitos destituídos de força obrigatória a não ser sob apelo moral às consciências, ou a "boa vontade" kantiana. O que poderia manifestar o caráter transgressor da ordem positiva vigente é conciliado em relação a mesma. Não haveria mudança, mas evolução do sistema jurídico em relação ao mundo da vida.

É evidente que, por outro lado, a afirmação histórica dessas declarações promulgou não apenas boas intenções, mas uma posição histórica da emancipação 
humana. É possível ver no ato de declarar direitos a potência de liberação do homem, porém, ao passo que há uma captura por instituições de poder - neste caso, o próprio Estado que se quer limitar - decorre um recrudescimento de sua finalidade primeira, deslocada para uma lógica de Razão de Estado. Assim, o que era potência se esvazia em poder.

A pretensão despolitizada do mito é seu efeito mais político: afirmar que os processos de exploração e dominação da sociedade capitalista são naturais, isto é, necessários e permanentes ainda que os modifiquem para continuar o mesmo. Como o mito rouba e restitui, a dissimulação de seu caráter político só pode ser efetuada em termos de naturalização do que não é natural. Logo, o mito avoca sua universalidade:

Na realidade aquilo que permite ao leitor consumir o mito inocentemente é o fato de ele não ver no mito um sistema semiológico, mas sim um sistema indutivo: onde existe apenas uma equivalência, ele vê uma espécie de processo casual: o significante e o significado mantêm, para ele, relações naturais. (BARTHES, 2010, p. 223)

Apesar de esclarecer como um mito se constitui, não há uma precisão de como ele ganha força. Nesse ponto, quinze anos após Mitologias, Barthes reavalia sua teoria do mito. No Rumor da língua, ele indica um aspecto aparentemente secundário do mito, porém relevante para analisar a força que ele adquire socialmente: a repetição do mito por meio da citação. O mito tem na repetição sua força, pois mais que avaliar seu signo é preciso analisar seu deslocamento na rede de comunicação (2004). Os dispositivos midiáticos obtiveram um nível de sistematização e ramificação próprios do código escrito. Da filosofia à propaganda, a articulação do sistema da escrita produz uma expansão múltipla da linguagem.

Qualquer discurso pode ser arremetido para qualquer lugar. Muitos mais do que compreensão do sentido que uma mensagem carrega, está na disposição de disseminála, logo, rompendo os limites do plenamente enunciável para a descontinuidade e expropriação do sentido. Uma frase de Platão pode ser repetida em diversos meios, sob diversos contextos, admitindo diversas significações. O paradoxal é que quanto mais citada, menos ela significa.

A proeza do mito é empobrecer o sentido. Isso marcaria, para Barthes, a destruição do próprio signo. A frase de Platão seria mais um artigo de consumo que um bem cultural. Nesse ponto, a perspectiva de Jacques Derrida pode ilustrar a dinâmica dessa economia simbólica. No mesmo período em que Barthes reavalia o mito, Derrida 
se dedica à reavaliação da teoria dos atos de fala de John Austin. O que chama atenção é a preocupação de ambos com os efeitos da citação no programa da comunicação social.

Desde o ensaio "Assinatura acontecimento contexto" e "Limited Inc.”, Derrida recepcionou a teoria dos atos de fala (speech acts) de John L. Austin. Ao longo de diversas referências e análises sobre essa teoria, como aponta Joseph Hillis Miller, Derrida renova sua discussão, apropriando-se e recriando seus termos para uma leitura dos textos éticos e políticos em geral. Em "Força de lei", o filósofo recorre à performatividade dos atos de fala a fim de elaborar uma análise sobre a linguagem jurídica.

Detido principalmente sobre as expressões to enforce the law ou the enforcebility of law e to address the law, o direito se perfaz sobre atos performativos. Assim, faz-se necessário um primeiro passo para compreender essa teoria implicada na desconstrução. O que interessa a este estudo, é a inversão que Derrida promove na distinção austianiana entre atos de fala constativos e performativos.

Sendo o processo de iteração do ato de fala condicionado ao jogo de linguagem, a própria interação do jogo depende da performance na transição de um modo de vida a outro: "A expressão jogo de linguagem deve aqui realçar o facto de que falar uma língua é uma parte de uma actividade ou de uma forma de vida" (WITTGENSTEIN, 1995, p. 189). Em contrapartida, os jogos de linguagem deixam um campo de investigação amplo, na medida em que a linguagem torna-se uma imanência múltipla e desnaturada, pois, ao mesmo tempo em que é reconhecida como instância elementar (ou originária) de formação do humano, ela consiste em uma diversidade de instituições.

Uma frase pode ser repetida em diversos momentos e locais, assim, sua força estará latente na repetição que promove seu deslocamento. Isso depende de sua força performativa. Portanto, mesmo um enunciado constativo depende de uma performatividade que o estabilize na comunicação e o torne citável. O mito é justamente esse ato performativo que se faz constativo. Ele impõe uma forma de significar uma situação como se estivesse descrevendo. Este paradigma está constituído por uma dimensão conflituosa da relação humana.

Os jogos se instituem em contendas dentro da comunidade: "é que falar é combater, no sentido de jogar, e que os atos de linguagem provêm de uma agonística geral” (LYOTARD, 2000, p. 17). A confrontação dos interesses comunitários produz uma multiplicidade de jogos na qual se conforma para que se possibilite a própria comunidade. Não apenas os códigos e as gramáticas, mas o que eles representam e 
definem enquanto estrutura comum do combate. Há uma circularidade entre o jogo e a comunidade que explica sua condição de imanência da linguagem em relação às formas de vida nela inserida:

$\mathrm{O}$ conceito de jogo da linguagem pretende acentuar que, nos diferentes contextos, seguem-se diferentes regras, podendo-se, a partir daí, determinar o sentido das expressões lingüísticas. Ora, se assim é, então a Semântica só atinge sua finalidade à Pragmática, pois seu problema central, o sentido das palavras e frases, só pode ser resolvido pela explicação dos contextos pragmáticos. (OLIVEIRA, op. cit., p. 139)

John Austin entende a constituição dessa imanência do jogo, efetivando-se em forças que emergem da linguagem. Não é à toa que o critério definitivo para os atos de fala reside na fortaleza que os sustenta. Dessa forma, não há a preocupação com a veracidade ou inveracidade, com a verdade ou a falsidade do ato. Ao contrário, o ato se erige na força, logo, a sua intensidade determina a posição em referência ao jogo. Por isso, o uso manifesta uma força estruturante que se posiciona frente a um contexto de forças dentro do jogo. O sentido, pois, é esse efeito de força.

Para delimitar os atos, Austin estabelece uma distinção fundamental. Os atos de fala são classificados em constativos ou performativos. Essa dicotomia se assenta numa convenção instituída previamente. Por um lado, quando se expressa uma determinada situação, enuncia-se uma descrição do acontecido. Por exemplo, "uma pedra caiu". Sendo assim, pode-se dizer também que "João matou Marcelo". Em ambas as proposições, é definida uma situação determinada. Então, o estímulo à percepção pode gerar um enunciado que apenas relate os elementos que constituíram o fato ou fenômeno. De outra monta, a própria enunciação pode efetivar uma ação. No instante em que, e.g, João disse a Marcelo que iria matá-lo, ele realizou uma ameaça.

O performativo institui uma forma de jogo em que a ação se manifesta na própria enunciação. Daí, "dizer é fazer" (to perform): "O nome é derivado, é claro, de agir (perform), o verbo usual com o substantivo ação indica que a emissão da expressão é a performance (performing) de uma ação" (AUSTIN, 1975, p. 6). Dessa forma, a linguagem expõe sua faceta pragmática. How to do things with words é a própria tentativa de interpretar a linguagem em sua dimensão ativa. Por isso, a força conduz ao movimento que institui a linguagem. Se há ação, logo, reside uma força ou um jogo de forças, isto é, um contexto sobre outro contexto.

Austin tipificou as forças que constituem um ato performativo para poder controlá-las. Apostou, então, na seriedade de sua teoria para manter uma definição 
adequada. Passa a ser condição de um ato esse arranjo exato das forças. Desse modo, em um ato há uma multiplicidade de forças que podem ser denominadas como locucionária, ilocucionária e perlocucionária. Essa multiplicidade, segundo Hillis Miller, produz uma catástrofe para a tentativa taxonômica dos performativos: "O projeto desfia-se numa crescente inimaginável complexidade, a complexidade do uso cotidiano na linguagem ordinária" (MILLER, 2001, p. 13). O próprio Austin reconhece a infelicidade (infelicity) comprometedora de sua teoria. Na tentativa de constatar (to describe) os atos e suas forças e distingui-los, ele passa a agir (perform) para conter sua proliferação.

É possível explicar cada uma dessas funções, ao passo que se entende o agenciamento delas no ato performativo. Primeiro, a locucionária sintetiza a totalidade da ação linguística. Logo, o uso da linguagem realiza a inteireza do ato, a força de uma só vez. A locução possui elementos que poderiam ser chamados de fenomênicos porque dispõem da possibilidade de uma experiência da linguagem. O refinamento proposto por Austin condiciona o ato locucionário a outros tipos atos:

$\mathrm{O}$ ato fonético é meramente um ato de emitir certos ruídos. $\mathrm{O}$ ato fático é a expressão de certos vocábulos ou palavras, de outro modo, ruídos de certos tipos, pertencendo a e pertencente a, um certo vocabulário, conformando e conformado a uma certa gramática. $\mathrm{O}$ ato rético é a performance de um ato de uso daqueles vocábulos com um mais ou menos certo sentido e referente definido.

Em seguida, denomina-se outra dicotomia. Há a função ilocucionária, atrelada a locução. A própria articulação rética da locução promove uma força ilocucionária informa-se um juízo na ação, ou seja, é o ponto em que algum valor é transposto no ato. Fazer, exprimir, apelar, ameaçar e prometer são ações contextualizadas e assumidas enquanto valores: "Como o ato ilocucionário não é, em muitos casos, explícito, sua força só pode ser explicitada por meio da consideração de todo o contexto" (OLIVEIRA, 2001, p. 159). Por exemplo, para perceber a força desse ato numa sentença judicial, é preciso contextualizar o veredito do juiz em relação a todo o sistema que ele movimenta (normas, servidores públicos, prédios e instalações, a toga etc.); todo o entorno força a consideração de tal decisão.

A imperatividade do mito adquire consistência na medida em que opera de forma sub-reptícia transmitindo seu valor parasitário. A infelicidade do mito é diante do enunciado performativo se passar por constativo, pois sua força ilocucionária fixa o conceito da constatação: "no sentido, já está constituída uma significação, que poderia 
facilmente bastar-se a si própria se o mito não a tomasse por sua conta e não a transformasse subitamente numa forma vazia, parasitária" (BARTHES, 2010, p. 208). O mito é parasita em relação a linguagem-objeto por impor um valor que empobrece a ação do enunciado: "Tornando-se forma, o sentido afasta a sua eventualidade; esvaziase empobrece, a história evapora-se, permanece apenas a letra" (BARTHES, 2010, p. 208).

De uma só vez, o jogo de linguagem se torna mais pobre (seu contexto) e a significação é cristalizada. A ordem do conhecer ou descrever uma realidade fica reduzida a uma perspectiva imperativa que se enuncia como a totalidade do real:

Para dizer a verdade, o que se investe no conceito é menos o real do que um certo conhecimento real; passando do sentido à forma, a imagem perde parte do seu saber: torna-se disponível para o saber do conceito. De fato, o saber contido no conceito mítico é um saber confuso, constituído por associações frágeis, ilimitadas. É preciso insistir sobre o caráter aberto do conceito; não é absolutamente uma essência abstrata, purificada, mas sim uma condensação informal, instável, nebulosa, cuja unidade e coerência provêm, sobretudo, da sua função. (BARTHES, 2010, p. 210)

A força desses atos se efetiva na medida em que aquele que acolhe os enunciados é afetado por isso: "Dizer algo produzirá comumente, e ainda normalmente, certos efeitos consequenciais sobre sentimentos, pensamentos ou ações da audiência, ou do falante ou da outra pessoa" (AUSTIN, 1975. p. 101). Determina-se, então, a força perlocucionária à capacidade de afetação frente ao outro através dos enunciados proferidos. Esse é o primeiro efeito retórico do uso da linguagem. Toda obra escrita, da arte a ciência, pretende produzir essa função. $\mathrm{O}$ mito necessariamente precisa criar a empatia em sua mensagem. A conformação das ações passa por influenciar o processo de afetação de cada indivíduo e da comunidade em geral:

O mito é um valor; não tem a verdade como sanção: nada o impede de ser um perpétuo álibi; basta que o seu significante tenha duas faces para sempre dispor de um "outro lado": o sentido existe sempre para apresentar a forma; a forma existe sempre para distanciar o sentido. E nunca há contradição, conflito, explosão entre o sentido e a forma, visto que nunca estão no mesmo ponto. (BARTHES, 2010, p. 215)

O valor do mito está em criar uma distância e um retardamento entre o significante e o significado. Para Derrida, isso é condição da linguagem como sistema. Derrida, por sua vez, aborda os atos de fala reforçando, naquele jogo de forças, o trabalho da iteração, isto é, a força performativa é repetitiva, desloca-se na citação e na capacidade de que cada ato pode ser reaproveitado nos contextos mais variados. A iterabilidade dos atos se faz possível no sistema da língua, como proposto por Saussure, 
na medida em que um signo não é definido por sua identidade, mas pela diferença em que se estabelece entre outros signos:

\begin{abstract}
Uma língua é, assim, concebida como um sistema de diferenças e isso leva ao desenvolvimento de distinções nas quais o estruturalismo e a semiótica se têm fiado: entre a língua como um sistema de diferenças (langue) e os eventos de fala que esse sistema possibilita (parole), entre o estudo da língua como um sistema em qualquer dado momento (sincrônico) e o estudo das correlações entre os elementos de diferentes períodos históricos (diacrônico), entre dois tipos de diferenças dentro do sistema, relações sintagmáticas e paradigmáticas, e entre os dois componentes do signo, significante e o significado. (CULLER, 1997. p. 114)
\end{abstract}

A diferença emerge uma vez constituído o pensamento sobre a linguagem. A possibilidade de representação perde potência em relação ao processo dinâmico que institui a remessa de signos no jogo. Pela diferença, o signo não suscita um valor estático ou um instante perpétuo e contínuo. Ao contrário, uma dinâmica diferida permite a relação entre o significante e o significado:

\footnotetext{
Numa língua, no sistema da língua, não há senão diferenças. Uma operação taxonômica pode pois fazer delas o inventário sistemático, estatístico e classificatório. Mas, por um lado, essas diferenças jogam: na língua, na fala e nas trocas entre a língua e a fala. Por outro lado, as diferenças são, elas próprias, efeitos. Não caíram do céu inteiramente prontas; estão tão pouco inscritas num topos noetos como prescritas na cera do cérebro. (DERRIDA, 199, p. 42-43)
}

Esta não se dá senão num deslocamento de espaço e tempo. Isto é, a interpretação de um signo nunca é contemporânea de sua apresentação: "este princípio da diferença como condição da significação afeta a totalidade do signo, isto é, simultaneamente a face do significado e a face do significante" (DERRIDA, 199, p. 42). Ao ler um texto, por exemplo, nem se apreende seu sentido de imediato, nem são saturadas as possibilidades de sua significação. Nunca um sentido, mas mais de um. Assim, a diferença constitui-se num movimento em que sua experiência perpassa tempo e espaço. Um pelo outro: "Se a palavra 'história' não comportasse em si o motivo de uma repressão final da diferença pode ser, à partida e na sua totalidade, "históricas" (DERRIDA, 199, p. 43).

Essa diferença no sistema da linguagem é a condição para afirmar a precariedade ou a infelicidade ou o parasitismo do mito. O mito tem uma história que quer fazer esquecer para ser apresentado como presente pleno. O problema é a distância criada entre a forma e o sentido. Nunca o mesmo lugar, o mito retarda sua significação plena, pois sua forma é esvaziada. No olhar de Derrida, surge, então, a différance enquanto um movimento em que ora significante se torna o significado, ora o inverso porque, ao 
mesmo tempo, um é possível pelo outro. Logo, este neologismo constitui uma ação que possibilita uma "história" da diferença:

O que o motivo da différance tem de universalizável em vista das diferenças é que ele permite pensar o processo de diferenciação para além de qualquer espécie de limites: quer se trate de limites culturais, nacionais lingüísticos ou mesmo humanos. Existe a différance desde que exista traço vivo, uma relação vida/morte ou presença/ausência. (DERRIDA, 2004, p.33)

O sentido é o produto de um espaçamento e temporalização dos elementos de um signo. Desse modo, não se pode controlar a univocidade do sentido, senão se der conta de que sua produção persiste sempre diferida e deslocada da experiência presente ou da idealização substancial. Como este controle está constantemente se defasando, não há senão múltiplos sentidos, na medida em que a cada lugar, um novo referencial; a cada tempo, uma outra duração.

Como o mito é uma deformação, ele redireciona o seu valor no ato performativo ao passo que é esvaziado de sentido. Paradoxalmente, ele é pleno (presente) e vazio (ausente): "O significante do mito se apresenta de uma maneira ambígua: é simultaneamente sentido e forma, pleno de um lado, vazio do outro lado" (BARTHES, 2010, p. 208). O mito burla esse processo de multiplicidade do sentido na medida em que controla o valor através do ato ilocucioário. Sua imperatividade é a consequência imediata:

\footnotetext{
O mito possui um caráter imperativo, interpelador: tendo surgido de um conceito histórico, vindo diretamente da contingência (uma aula de latim, O Império ameaçado), é a mim que ele se dirige. Está voltado para mim, impõeme a sua força intencional; obriga-me a acolher a sua ambiguidade expansiva. (BARTHES, 2010, p. 216)
}

Esse processo de imposição de um valor só funciona se, na sua repetição, ele preserva o conceito que o mito faz comunicar. Por isso, ao mesmo tempo que se vale da diferença de cada iteração ele cessa a possibilidade de diferir. A iterabilidade se manifesta na legibilidade que proporciona. Um signo só pode ser apreendido se for passível de repetição: o texto vem a ser para si de novo. No mito, o texto vem a ser de novo o mesmo. Ele se aproveita da inversão promovida por Derrida. $\mathrm{O}$ ato performativo auxilia a constatar a realidade.

$\mathrm{Na}$ ensaio "Assinatura acontecimento e contexto" de Derrida, o performativo suplementa o constativo, pois esse seria um caso particular de performatividade. Quando um cientista descreve um fenômeno, precisa se sedimentar sobre uma gramática específica de sua ciência. A constatação do fato se sustenta em uma promessa ou 
compromisso em relação a este código científico. Há um dever da descrição contextualizada. Logo, uma teoria fracassará, ou não, à medida que se adeque ao contexto de sua legitimação. Por trás de todo constativo, há um performativo legitimador e suplementar.

$\mathrm{Na}$ diferença de forças performativas (locucionárias, ilocucionárias, perlocucionárias), o conceito de contexto sofre uma mudança a partir das linhas de fuga da iterabilidade. Esta possibilita o desenlace da trama vertendo uma reorganização dos rastros e dos referentes. Desse modo, a iteração desconstrói o contexto sendo indesconstrutível, pois a repetição age de uma só vez para si não permitindo, então, a saturação do contexto:

A pretensa reconstituição de um contexto permanece sempre uma operação performativa e não puramente teórica. Para retornar à sua fórmula, "o próprio projeto de tentar fixar o contexto dos enunciados" talvez não seja "algo politicamente suspeito" certamente, mas não pode ser mais algo de apolítico ou politicamente neutro. E a análise de da dimensão política de toda determinação contextual nunca é um gesto puramente teórico. É sempre uma avaliação política, mesmo que o código dessa avaliação seja sobredeterminado, rebelde às classificações (por exemplo, direita/esquerda) e por vir - prometido - mais que dado. (DERRIDA, 1991a, p. 178)

Derrida chama atenção à política em torno da teoria dos atos de fala que se promove em direção ao controle do discurso num contexto social. Para tanto, as convenções permitem vislumbrar um controle pragmático dos discursos:

Há os gramáticos, linguistas, juristas "teóricos", que dizem, descrevem, explicam a norma, sem requerer sua aplicação, pelo menos a aplicação imediata, pela força (física ou simbólica). Outras funções em fazer respeitar a lei e dispor de uma força considerada legítima para tanto. Esses dois tipos de função e essas duas maneiras de "fixar" as regras e também, para retomar sua expressão, "fixar" o "contexto dos enunciados" podem associar o teórico do direito, o legislador (o inventor, ou o próprio primeiro signatário de uma constituição, ou aqueles em nome dos quais ele pretende agir) e o poder executivo. (DERRIDA, 1991c, p. 184)

São agentes investidos performativamente que asseguram a convenção que controla a performatividade. Nesse sentido, constrói-se um aparato para a regulação discursiva. Esta é a polícia repressiva mantendo um controle contextual da sociedade. Bem próximo a essa perspectiva, Foucault expõe as interdições em A ordem do discurso: "Sabe-se que não se tem o direito de dizer tudo, que não se pode falar tudo em qualquer circunstância, que qualquer um, enfim, não pode falar qualquer coisa" (1996, p. 9). Assim, elenca três interdições que, em suas reentrâncias, fazem circular e selecionar os discursos, quais sejam, o tabu do objeto, o ritual das circunstâncias e o direito privilegiado ou a exclusividade do sujeito que fala. 
A proximidade de Derrida está em justamente dar ênfase ao discurso policiado ou a vigilância sobre os enunciados performativos e performances:

Há um policial brutal e de preferência "fisicamente" repressiva (mas a polícia nunca é puramente física) e há polícias mais refinadas, mais "culturais" ou "espirituais", mais nobres. Mas toda instituição destinada a fazer respeitar a lei é uma polícia. Uma academia é uma polícia, quer a entendamos no sentido de Academia francesa, cuja tarefa essencial é fazer respeitar a língua francesa, decidir o que deve ser bom emprego do francês. [...] Não há sociedade sem polícia, mesmo que se possa sempre sonhar com formas mais sublimes, mais refinadas ou menos vulgares de polícia. (DERRIDA, 1991c, p. 185)

O direito é o paradigma para essa perspectiva de análise dos atos de fala, assim como, do mito. É possível perceber isso - e reiterar o dever dessa análise - nas Declarações e nos atos que instituem os direitos e suas instituições:

O paradoxo que encontramos não é exclusivo para os documentos revolucionários. Ele vai acompanhar muitas novas constituições e decretos de direitos humanos, que partam de ordem constitucional pré-existente. Um projeto de lei de direitos ou constituição tem dois aspectos: a enunciação, o ato de declarar (performativa) e, por outro, a instrução, o conteúdo da enunciação (constativa). A dimensão performativa age com a afirmação de que os legisladores que eles estão autorizados a pronunciar direitos e, ao fazê-lo, ele apresentá-los. As reivindicações específicas à "vida, liberdade e busca da felicidade", por outro lado, estado esses direitos e dar-lhes a substância. O domínio do paradoxo prolifera rapidamente para outros que impeçam declarações e tratados nunca ser totalmente implementado ou de aterramento de uma ordem social estável. (DOUZINAS, 2000, p. 94)

É imperativo compreender que a força dos atos de fala, sua performatividade, não é levada em abstrato. Só é possível dentro de um sistema de administração e governo da violência socialmente instituída. A violência é mais um jogo que marca o modo de vida social. O mito é o produto desse processo de controle do sentido na sociedade. Tanto Barthes quanto Derrida reforçam essa perspectiva de que o trabalho do mito, sua circulação e consumo, instauram a própria reprodução do poder na sociedade moderna. Em seguida, é preciso pensar a violência mítica que configura os Direitos Humanos.

\section{O mito e a ação: a violência mítica na constituição dos Direitos Humanos em}

\section{Benjamin e Derrida.}

Se o mito é uma forma de comunicação que nos impele a um determinado comportamento, é preciso definir como há este deslocamento da instância da linguagem para a ação. Sendo assim, a reflexão que orienta este trabalho é a de Walter Benjamin, 
no ensaio "Para uma crítica da violência", pois parece oferecer uma chave de leitura da relação entre direito, mito e violência. O mito é a forma que revela a relação intrínseca entre os outros dois.

Um ponto de partida para compreender a crítica benjaminiana passa pela influência de Sorel. O mito desempenha uma função relevante em ambos trabalhos, porém as posições são distintas. Por um lado, Sorel concebe o mito como uma imagem que impele a ação a partir do momento que instaura um sentido de mundo para o agente. Sua finalidade é constituir uma convicção para a ação revolucionária. Por outro, Benjamin critica o mito pois edifica uma ordem em que a vida será aprisionada num simulacro de natureza através da imposição de um destino. A vida de um homem seria vinculada a uma forma como se está fosse sua única condição. Enquanto a violência soreliana depende de um mito para circular entre os agentes, a violência benjaminiana se consuma no mito que a justifica.

Ao que parece, Benjamin assume a tese de Sorel para criticá-la especificamente no processo de mitificação. $O$ mito soreliano constitui-se não no processo revolucionário enquanto liberação, mas no revés de um aprisionamento a uma visão total da vida: "Sorel volta a levar a sério as aguerridas e heróicas ideias vinculadas à luta e à batalha, os quais encarnam os magnos impulsos da vida intensa" (SCHMITT, 2001,

p. 69). Há uma concentração da análise do efeito psicológico do mito sobre o engajamento proletário:

(...) coleções de imagens que, em conjunto e através da intuição sozinho, antes de quaisquer análises consideradas são feitas, são capazes de evocar a massa de sentimentos que correspondem à manifestação Diferente da guerra empreendida pelo socialismo contra a sociedade moderna. (SOREL, 1999, 113)

Acaba por enaltecer aquilo que mesmo quer criticar: a violência como motor do Estado. Se a acusação de fascismo a Sorel é descabida, não se pode dizer o mesmo de que, ao levar ao extremo sua noção política de mito, este assume contornos totalitários pela própria intensidade que quer manifestar. A ação revolucionária não seria uma liberação. Ao contrário, seria o perigo de replicação do princípio de conquista que move o Estado. Essa inflexão é a própria deformação do mito em Barthes. Tomar as possibilidades de sentidos à vida política sob uma única forma é a própria naturalização da revolução como um processo fadado a acontecer.

O mito impõe uma ordem de fatos, não um teor de verdade. Sua função é convencer o oprimido a assumir a batalha, seja do sindicato, do partido ou do Estado. 
Nesse ponto, o teor de verdade não é a verdade em si. Precisamente, a condição de que a verdade só pode ser forjada num resgate do processo histórico que constituiu as situações fáticas presentes. O teor de verdade é o impulso para a experiência (Ehfarung), ou seja, atravessar os limites que as situações de fato nos impõem. Tal teor possibilita a abertura a um sentido de mundo e não ao aprisionamento mundano.

Essa disposição está na reflexão, pontual e contingente, da crítica. $\mathrm{O}$ "eu” reflete na medida em que está focado em uma situação, porém, na conciliação consigo mesmo, encontra um limite e uma passagem para novas disposições. Por isso, a descontinuidade é uma marca da concepção histórica benjaminiana. A cada vez que um sujeito se dispõe para algo que não é ele, seu retorno é uma diferença de si para si.

Uma história não vivida pelo sujeito, mas que o acomete para ele analisar um passado num presente. O contexto presente e as ruínas do passado dispõem um conflito sobre a contingência do próprio sujeito que investiga a história. Ciente disso, Benjamin compreende que a crítica do presente só pode ser realizada com a leitura do passado. $\mathrm{O}$ mito como uma situação material não suporta sua própria história, pois quer eternizar um presente esvaziando seu passado.

O mito benjaminiano circunscreve uma articulação entre o Direito e o Destino. Embora, não se possa sustentar uma carga religiosa nesses termos, o Destino não é derivado da Religião nem do Direito. Antes, esses se investem dele para dominar a vida enquanto tal. $\mathrm{O}$ destino é uma condição de existir e do sentido que se dispõe a própria vida. Na produção de dispositivos religiosos e jurídicos, há uma conformação da vida em parâmetros prescritos por essas instituições. A dominação é justamente modular a vida pela regulação. Assim, a regra imputa um destino, antes de uma conduta ou uma punição. O mito é criado como forma de mediar o destino e a vida:

Este erige as leis do destino, da infelicidade e da culpa à condição de medida da pessoa; seria falso admitir que apenas a culpa se encontra neste nexo com o direito; pode-se provar, muito mais, que qualquer culpabilidade jurídica nada é do que infelicidade. Por engano, por ter sido confundida com o reino da justiça, a ordem do direito - que é apenas um resíduo do plano demoníaco na existência humana, na qual os princípios jurídicos não determinam apenas as relações entre os homens, mas também destes com os deuses - manteve-se para além do tempo que inaugurou a vitória sobre os demônios. (BENJAMIN, 2011, p. 93)

Destino, Direito e Mito formam uma tríade do domínio sobre a vida a fim de torná-la uma "mera vida". Por esse viés, pouco há em função da visão ética. É no nível do existir que o Direito primeiro se institui. Essa é a tragédia moderna: a existência livre do homem edifica seu aprisionamento no Direito: 
O direito como o reino do destino é, portanto, o reino da, uma necessidade demoníaca natural, um remanescente dos estágios mais baixos de desenvolvimento humano. Não foi na lei, mas na tragédia, Benjamin escreve, que o homem violou destino demoníaco pela primeira vez e compreendeu a possibilidade de liberdade. (SALZANI, 2008, p. 25)

Todo juízo no Direito tem a pretensão de instaurar uma ordem necessária, ainda que positivamente artificial. Na saída do dever possível para a situação irredutível, as instituições judiciárias vertem seus esforços. Impor um destino é formalizar a vida em um ciclo ou simulacro de natureza. Não há sacralidade para essa mera vida. Sua condição é prisional, no interior de uma natureza mitificada, necessária por convenção.

É preciso bater numa tecla. Ao longo do debate, não se pode esquecer que a palavra Gewalt significa em alemão tanto violência quanto poder. As traduções portuguesa e brasileira notam essa precaução. Então, esta vida dupla de um nome será o mote para o desenvolvimento do ensaio de Benjamin e a chave de leitura para os comentadores. Desde a primeira vez que se pronuncia a palavra, trate-se de violência sob o espectro do poder.

O objeto primário da investigação é o monopólio da violência do Estado Moderno. É preciso compreender como esse pressuposto político-jurídico foi arquitetado historicamente. Em verdade, ele é o conceito e o valor que o mito tem por finalidade restituir em cada ato violento nas interações sociais. Antes mesmo do ensaio da crítica, Benjamin já expõe esse problema num fragmento não publicado, de 1920, sobre "O direito de usar força", comentando um texto homônimo publicado no Jornal do Socialismo Religioso. Assim, uma passagem na íntegra para discussão:

"O sistema jurídico tende a reagir às tentativas de destruí-lo, recorrendo à coerção, seja coercitivamente para preservar ou restaurar a ordem correta (right)."

Essa declaração está correta em si mesma, mas é um equívoco explicar isso com referência à tendência interna do direito estabelecer sua autoridade. $\mathrm{O}$ que está em questão aqui é a realidade subordinada ao que a lei endereça. $\mathrm{O}$ que está em questão é o ritmo violento da impaciência na qual o direito existe e tem sua ordem temporal, como oposto ao bom (?) ritmo da expectativa em que eventos messiânicos se revelam. (BENJAMIN, 1996, p. 231)

Os ditos eventos messiânicos não constituem o objeto deste trabalho, porém seriam os eventos que tornariam possíveis as transformações sociais. O que interessa é que a causalidade imanente (a relação interna entre violência, mito e direito). Podemos observar o quanto o direito age como um fim em si mesmo. Isso inaugura o problema do mito do Estado de Direito. A auto-referência é própria da mítica formação que o 
direito se exalta em função da sociedade e dos indivíduos em geral. Por isso, é preciso retornar as justificações para o monopólio.

O mito do monopólio é a instituição do destino que o Direito assume na vida. Elidir, mesmo aparentemente, as possibilidades de convivência fora das categorias jurídicas. O direito se torna a própria condição para a vida humana:

O "mito" é a prisão de uma vida reduzida a "vida natural", ou seja, "a mera vida", culpa e infelicidade, que arrasta o homem para baixo e trazer desastre sobre eles: o eterno retorno da violência. A esfera ética é considerada como uma quebra do complexo demoníaco do mito-destino-culpa que é próprio de vida natural, uma quebra em "algo maior": übernaturlichen Lebens (vida sobrenatural), uma vida propriamente humana que se originaria história humana adequada. (SALZANI, 2008, P. 27)

Não à toa, o Estado é bastante seletivo e específico na sanção dessas práticas violentas. Há de se compreender que as práticas mais simples no direito só ganham efetiva garantia por carregaram consigo o espectro de poder da violência. Ninguém celebra um contrato, por exemplo, dentro de parâmetros pacíficos que não saiba que possa recorrer a coerção:

Se, de fato, a violência [Gewalt], a violência coroada pelo destino, for a origem do direito, então pode-se prontamente supor que no poder [Gewalt] supremo, o poder sobre a vida e a morte, quando este adentra a ordem do direito, as origens dessa ordem se destacam de maneira representativa no existente e nele se manifestam de forma terrível. (BENJAMIN, 2011, p. 134)

Definir o destino de alguém é um dos poderes maiores do judiciário, por exemplo. Os modos e métodos judiciais qualificam a vida de um indivíduo no nível mais originário a fim de definir seu caráter no ponto de sua vida nua ou mera vida. Eis o criminoso, o pai, o filho, o devedor. Não são acidentais, mas para funcionarem como processo de expiação da própria subjetividade determinada pela lei.

O que o Direito nos revela é um paradoxo constitutivo de sua condição. Ele tenta representar o que não possui representação. A tática constante de formalizar na representação da violência aquilo que não se dá efetivamente nela. Por isso, o poder sobre a vida e a morte fascina a condição soberana do direito. A pena de morte passa a ser uma questão sempre polêmica e incapaz de uma representação:

Pois a violência na instauração do direito tem uma função dupla, no sentido de que a instauração do direito almeja como seu fim, usando a violência como meio, aquilo que é instaurado como direito, mas no momento da instauração não abdica da violência; mais do que isso, a instauração constitui a violência em violência instauradora do direito - num sentido rigoroso, isto é, de maneira imediata - porque estabelece não um fim livre e independente de violência [Gewalt], mas um fim necessário e intimamente vinculado a ela, e o instaura enquanto direito sob o nome de poder [Macht]. A instauração do direito é instauração de poder e, enquanto tal, um ato de manifestação 
imediata da violência. A justiça é o princípio de toda, instauração divina de fins, o poder [Macht] é o princípio de toda a instauração mítica do direito. (BENJAMIN, 2011, p. 148)

Por isso mesmo a crítica benjaminiana da violência quer deslindar, separar uma construção externa entre a ação da violência e a representação do Direito. A pretensão do Direito consiste em dar nome a toda violência para representá-la para si. Contudo, ao mesmo tempo, arrisca-se em se perder pela violência em si irrepresentável. Construindo, assim, uma relação transcendente, deslocada de uma avaliação da violência em si. Essa é a consolidação do mito no direito.

Derrida assume o esteio de Benjamin para desenvolver as implicações míticas no interior a aplicação do Direito (enforceability of law) a fim de declarar o Direito ou os direitos (to address the law or the rights). Esse processo depende da pressuposição da revolução do mito, ou seja, na constituição do monopólio da violência do Estado. É o próprio efeito de roubar a disposição particular da violência natural para a restituição num sistema de mediações violentas:

\footnotetext{
Uma revolução "conseguida", a fundação de um Estado "conseguida" (um pouco no sentido em que se fala de um "felicious" "performative speech act”) produzirá posteriormente (après coup) o que antecipadamente [d'avance] estava destinada a produzir, a saber, modelos interpretativos próprios para ler retroactivamente, para dar sentido, necessidade e, sobretudo, legitimidade à violência que produziu, entre outros, o modelo interpretativo em questão, isto é, o discurso da sua auto-legitimação. (2003, p. 67)
}

A violência que instaura o Direito rouba a legitimidade de exercê-la das outras entidades sociais e é restituída, em sua performatividade, ao passo que organiza uma distribuição dos meios violentos legítimos. Assim, entre todas as possibilidades de significar a violência socialmente, apenas a forma jurídica é interpretativamente válida. Toda violência legítima pressupõe um "em nome de", seja do ordenamento, da Constituição ou leis constitucionais, seja em nome dos Direitos Humanos que fixam uma forma para a condição humana. A restituição será necessariamente conservadora:

\footnotetext{
Uma fundação é uma promessa. Toda a posição (Setzung) permite (termet) pro-mete (pro-met): posiciona metendo e prometendo. E mesmo se uma promessa não for, de facto, mantida, a iterabilidade inscreve a promessa de salvaguarda no instante mais eruptivo da fundação. Inscreve assim a possibilidade da repetição no coração do originário. Melhor, ou pior, ela está inscrita nesta lei de iterabilidade, mantém-se sob a sua lei ou diante da sua lei. Consequentemente, não há já mais fundação pura ou posição pura do direito, logo, pura violência fundadora, tal como não há violência puramente conservadora. A posição é já iterabilidade, apelo à repetição autoconservadora. Por sua vez, a conservação é ainda re-fundadora para poder conservar o que pretende fundar. Não existe portanto oposição rigorosa entre a posição e a conservação, mas apenas aquilo que chamarei (e que Benjamin
} 
não nomeia) uma contaminação differencial (differantielle) entre as duas, com todos os paradoxos que tal pode induzir. (DERRIDA, 2003, p. 69-70)

A revolução marca o mito. A relação interna e contaminada entre o poder constituinte e o poder constituído, a posição e a conservação, a violência que instaura e a que conserva remetem ao ciclo de aprisionamento da vida a forma mítica. Seria possível, não neste trabalho, catalogar e analisar decisões judiciais e medidas jurídicas que reativam em seus discursos e suas interpretações a violência mítica em toda sua performatividade. A decisão sobre direitos (rights) não pode exceder o Direito (law) a não ser na medida em que o direito (right) de julgar e decidir sobre a vida dos direitos (rights) acessa ao extremo da fundação do Direito (law). Tais atos jurídicos conjugam aquilo mesmo que não se poderia acessar, o fora do direito, isto é, o poder (Gewalt) de transgredir os limites do destino.

\section{Considerações finais - para o início de um projeto}

À guisa de conclusão, pretende-se assumir a precariedade da exposição na medida em que não se pode explorar melhor outros exemplos ou valer-se de um estudo de caso para melhor avaliação do objetivo. A relação entre Direito (e sua linguagem), violência e mito é observada na dinâmica dos atos de fala enquanto modelo de análise para a semiologia do poder que perfaz as instituições jurídicas. Pretende-se, no futuro, explicitar essas questões sobre alguns aspectos que tornam esta conclusão uma carta de intenções.

1. Não há como separar a forma do mito da violência que ele reitera. Por isso, é preciso criar um corpus de pesquisa focados nos signos jurídicos, principalmente, aqueles que permeiam o discurso judiciário;

2. Há uma necessária relação entre a história dos Direitos Humanos e sua construção mitificada. Ao menos, no que diz respeito a forma como é contada essa história centrada nas revoluções burguesas, nos Estados nações (soberanos) europeus e na democracia moderna. Tanto nas declarações como nas políticas implementadas há um reforço da violência mítica. A precariedade dos dispositivos a disposição para concretização dos DH. A jurisprudência em torno dessa questão é um exemplo por meio de decisões que reforçam a Razão de Estado ante as demandas da vida humana; 
3. É imperioso pensar a noção de Direitos (Humanos) fora do ciclo Direito-MitoViolência. Por um lado, buscar um novo estatuto para os direitos em geral é reativar a ação humana política como potência de resistir e transformar o poder. Por outro, é de algum modo solicitar a condição ambígua do mito, enquanto roubo e restituição. A revolução do mito tem a função de conservar o valor que ele implica. Contudo, é possível criar um mito de terceira ordem para deslocar ainda mais essa restituição. Talvez seja nesse ponto que Sorel venha a potencializar Benjamin, na medida em que a violência divina pode ser roubo e restituição do mito enquanto tal.

\section{Referências}

AUSTIN, J.L. How to do things with words. 2. ed. Oxford-RU: Oxford University Press, 1975.

AVILA NIETO, C. (2012). El mito como elemento estratégico de comunicación política: aplicación del modelo de Barthes al caso ecuatoriano. Cuadernos de Información 31, 139150. DOI: $10.7764 /$ cdi. 31.447

BARTHES, R. Mitologias. São Paulo: Difel, 2010.

O rumor da língua. São Paulo: Martins Fontes, 2004.

BENJAMIN, W. The right to use force. in: Selected writings. Cambridge-USA; London: The Belknap Press of Havard University Press, 1996.

Escritos sobre mito e linguagem (1915-1921). São Paulo: Duas Cidades; Ed. 34, 2011.

DERRIDA, J. Limited Inc.Trad. Constança Marcondes Cesar. Campinas: Papirus, 1991a.

Margens da Filosofia. Trad. Joaquim Torres Costa e António M. Magalhães. Campinas: Papirus, 1991b.

A farmácia de Platão. Trad. Rogério da Costa. São Paulo: Iluminuras, 1991c (Biblioteca Pólen).

Força de lei: O "fundamento místico da autoridade". Porto-Portugal: Campo das Letras, 2003a.

; ROUDINESCO, E. De que manhã: diálogo. Rio de Janeiro: Jorge Zahar Ed., 2004a. $27 \mathrm{p}$.

Otobiografias. La enseñanza de Nietzsche y la política del nombre próprio. Buenos Aires: Amorrortu, 2009. 
DOUZINAS, Costas. The end of human rights: critical legal thought at the turn of the century. Oxford-UK: Hart, 2000.

FOUCAULT, M. A ordem do discurso: Aula inaugural no Collège de France, pronunciada em 02 de dezembro de 1970. 3. ed. São Paulo: Loyola, 1996.

LYOTARD, Jean-François. A condição pós-moderna. 6. ed. Rio de Janeiro: José Olympio, 2000.

MILLER, J.H. Speech acts in literature. Stanford-California-USA: Stanford University Press, 2001.

SALZANI, Carlo (2008). Violence as Pure Praxis: Benjamin and Sorel on Strike, Myth and Ethics. Colloquy 16:18-48.

SCHMITT, C. La teoria política del mito. In: AQUILAR, H. O. Carl Schmitt, el teólogo de la política. México: FCE, 2001.

SOREL, G. Reflections on Violence. Cambridge: Cambridge UP, 1999.

WITTGENSTEIN, Ludwig. Tratado Lógico-Filosófico e Investigações Filosóficas. 2. ed. Lisboa: Fudação Calouste Gulbenkian, 1995. 